\title{
Could offspring predation offset the successful reproduction of the arctic copepod Calanus hyperboreus under reduced sea-ice cover conditions?
}

\author{
Gérald Darnis $^{\mathrm{a}, *}$, Anette Wold ${ }^{\mathrm{b}}$, Stig Falk-Petersen ${ }^{\mathrm{c}, \mathrm{d}}$, Martin Graeve ${ }^{\mathrm{e}}$, Louis Fortier ${ }^{\mathrm{a}}$ \\ ${ }^{a}$ Québec-Océan, Département de biologie, Université Laval, Québec, QC G1V 0A6, Canada \\ ${ }^{\mathrm{b}}$ Norwegian Polar Institute, N-9296 Tromsø, Norway \\ ${ }^{\mathrm{c}}$ Akvaplan-niva, Fram Centre for Climate and the Environment, N-9296 Tromsø, Norway \\ d Institute of Arctic and Marine Biology, Faculty of Biosciences, Fisheries and Economics, University of Tromsø, N-9037 Tromsø, Norway \\ ${ }^{\mathrm{e}}$ Alfred Wegener Institute for Polar and Marine Research, Am Handelshafen 12, D-27570 Bremerhaven, Germany
}

\section{A R T I C L E I N F O}

\section{Keywords:}

Arctic Ocean

Beaufort Sea

Marine ecology

Zooplankton

Calanus hyperboreus

Lipids

\begin{abstract}
A B S T R A C T
Life cycle and reproduction of Calanus hyperboreus were studied during a year of record low ice cover in the southeastern Beaufort Sea. Stages CIV, adult females and CV dominated the overwintering population, suggesting a 2- to 3-year life cycle. Within two spring-summer months in the upper water column females filled their energy reserves before initiating their downward seasonal migration. From February to March, vigorous reproduction (20-65 eggs $\mathrm{f}^{-1} \mathrm{~d}^{-1}$ ) delivered numerous eggs $\left(29000\right.$ eggs $\mathrm{m}^{-2}$ ) at depth and nauplii N1-N3 (17000 ind. $\mathrm{m}^{-2}$ ) in the water column. However, CI copepodite recruitment in May, coincident with the phytoplankton bloom, was modest in Amundsen Gulf compared to sites outside the gulf. Consequently, $C$. hyperboreus abundance and biomass stagnated throughout summer in Amundsen Gulf. As a mismatch between the first-feeding stages and food was unlikely under the favourable feeding conditions of April-May 2008, predation on the egg and larval stages in late winter presumably limited subsequent recruitment and population growth. Particularly abundant in Amundsen Gulf, the copepods Metridia longa and C. glacialis were likely important consumers of $C$. hyperboreus eggs and nauplii. With the ongoing climate-driven lengthening of the ice-free season, intensification of top-down control of $C$. hyperboreus recruitment by thriving populations of mesopelagic omnivores and carnivores like $M$. longa may counteract the potential benefits of increased primary production over the Arctic shelves margins for this key prey of pelagic fish, seabirds and the bowhead whale.
\end{abstract}

\section{Introduction}

Sea-ice variability is a major structuring factor of the Arctic marine ecosystem, the climate-driven decline in ice-cover extent is bound to have serious implications for all levels of the trophic web (Darnis et al., 2012). A $20 \%$ increase in phytoplankton annual net primary production over the Arctic Ocean and its marginal seas between 1998 and 2009 was driven by the lengthening of the growth season ( +45 days) (Arrigo and van Dijken, 2011). Zooplankton of the genus Calanus are expected to respond positively to such rise in pelagic primary production, particularly on the continental margins prone to upwelling (Tremblay et al., 2011).

The oceanic large copepod Calanus hyperboreus constitutes the prime herbivore in the Arctic Ocean and deep margins of its shelf seas where the species dominates mesozooplankton biomass (Auel and Hagen, 2002; Darnis and Fortier, 2012; Kosobokova and Hirche, 2009; Ringuette et al., 2002). This endemic species has developed specialized life-history strategies to adapt to a short and unpredictable season of food supply constrained by the variable timing of ice melt (FalkPetersen et al., 2009, 2007). When C. hyperboreus has accumulated sufficient lipid reserves, it performs a long-range seasonal migration to spend the cold and dark overwintering season of up to 10 months in diapause at depths several hundred to thousand metres below the surface (Ashjian et al., 2003; Dawson, 1978; Hirche, 1997; Vinogradov, 1997). This copepod stores lipids, mostly as wax esters, in oil sacs exceeding 65\% of dry mass (Falk-Petersen et al., 2009; Pasternak et al., 2001). The wax esters contain high amounts of the long-chained 20:1 and 22:1 fatty acids and fatty alcohols of high energy content per unit mass that are synthesized de novo by Calanus to provide energy for overwintering and reproduction (Sargent and Falk-Petersen, 1988). Without food, winter reproduction is solely fuelled by the females' lipid reserves (Hirche and Niehoff, 1996). The adaptive advantage for the offspring, hatched ahead of the phytoplankton bloom and slowly developing on endogenous reserves to first-feeding stage Nauplius 3 , is

\footnotetext{
* Corresponding author.

E-mail address: Gerald.Darnis@qo.ulaval.ca (G. Darnis).
} 
that they are ready beforehand to fully exploit the intense but brief summer season of biological production (Conover and Huntley, 1991). Within a few weeks, grazing on microalgal cells enables them to rapidly grow and recruit to copepodites large enough to overwinter (CIIIadults). Over its vast geographical range, $C$. hyperboreus can modulate its generation time between 1 and at least 4 years depending on prevailing environmental conditions (Hirche, 1997).

To model the response of this key copepod to changes in the Arctic sea-ice regime, important traits of its life history need to be better documented, particularly for the poorly studied winter months when reproduction occurs. In this study, we provide a detailed description of the reproduction cycle and population dynamics of $C$. hyperboreus based on a quasi-annual time series during a period of record low ice cover in the southeastern Beaufort Sea (October 2007-July 2008) that is compared with the situation during an average year (2003-2004). We address the hypothesis presented by Ringuette et al. (2002) that a lengthening of the ice-free season on Arctic shelves will promote population growth of large herbivore copepods such as $C$. hyperboreus.

\section{Material and methods}

\subsection{Study area}

The Amundsen Gulf system, including Franklin and Darnley bays to the south and bounded by Banks Island to the north, bridges the Beaufort Sea and eastern Mackenzie Shelf with the Canadian Arctic Archipelago (Fig. 1). Three main water masses lie in the region: the Polar-Mixed Layer (PML; salinity < 31.6; 0-50 m), the Pacific Halocline (PH; $32.4<\mathrm{S}<33.1 ; 50-200 \mathrm{~m}$ ), and the warmer Atlantic Waters (AW; $>$ > 34; > $200 \mathrm{~m}$ ) (Carmack and Macdonald, 2002). The generally weak surface circulation is influenced by the anticyclonic Beaufort Gyre that carries the pack ice and surface waters westward toward the Canada Basin (Carmack and Macdonald, 2002; Ingram et al., 2008). Below $\sim 80 \mathrm{~m}$ depth, the Beaufort shelf-break jet transports waters of both Pacific and Atlantic origin along the continental slope and into Amundsen Gulf (Carmack and Macdonald, 2002; Pickart, 2004). Within the gulf, deep circulation is usually weak and highly variable (Ingram et al., 2008). Sea-ice starts to form in October at the coastal margins of the gulf and consolidation over the entire area is completed by December (Galley et al., 2008). Ice breakup usually begins in late May-early June (1979-2000 average) and the section of the flaw lead polynya at the mouth of the gulf enlarges to form the Cape Bathurst Polynya complex (Barber and Hanesiak, 2004). In Franklin Bay, robust landfast ice coverage usually lasts until June. Remote sensing revealed considerable inter-annual variability in the extent and persistence of open water (Arrigo and van Dijken, 2004).

\subsection{Sampling}

Zooplankton samples were collected between 16 October 2007 and 30 July 2008 at 101 stations (Supplementary Table 1) in the southeastern Beaufort Sea during the International Polar Year expedition of the research icebreaker CCGS Amundsen (Fig. 1). Most of the stations (88) were sampled in western Amundsen Gulf and the 13 remaining were located on the Mackenzie outer shelf and slope, Darnley and Franklin bays, and along the northwest coast of Banks Island as far north as McClure Strait. Sampling for abundance estimates, egg production experiments and carbon-content measurement on Calanus hyperboreus had also been carried out at 88 stations (Supplementary Table 2) in the southeastern Beaufort Sea during a previous overwintering program, the Canadian Arctic Shelf Exchange Study (CASES) project from September 2003 to September 2004 (Fortier and Cochran, 2008). The CASES sampling grid covered mainly the Mackenzie shelf and slope and Amundsen Gulf (Fig. 1), whereas winter sampling took

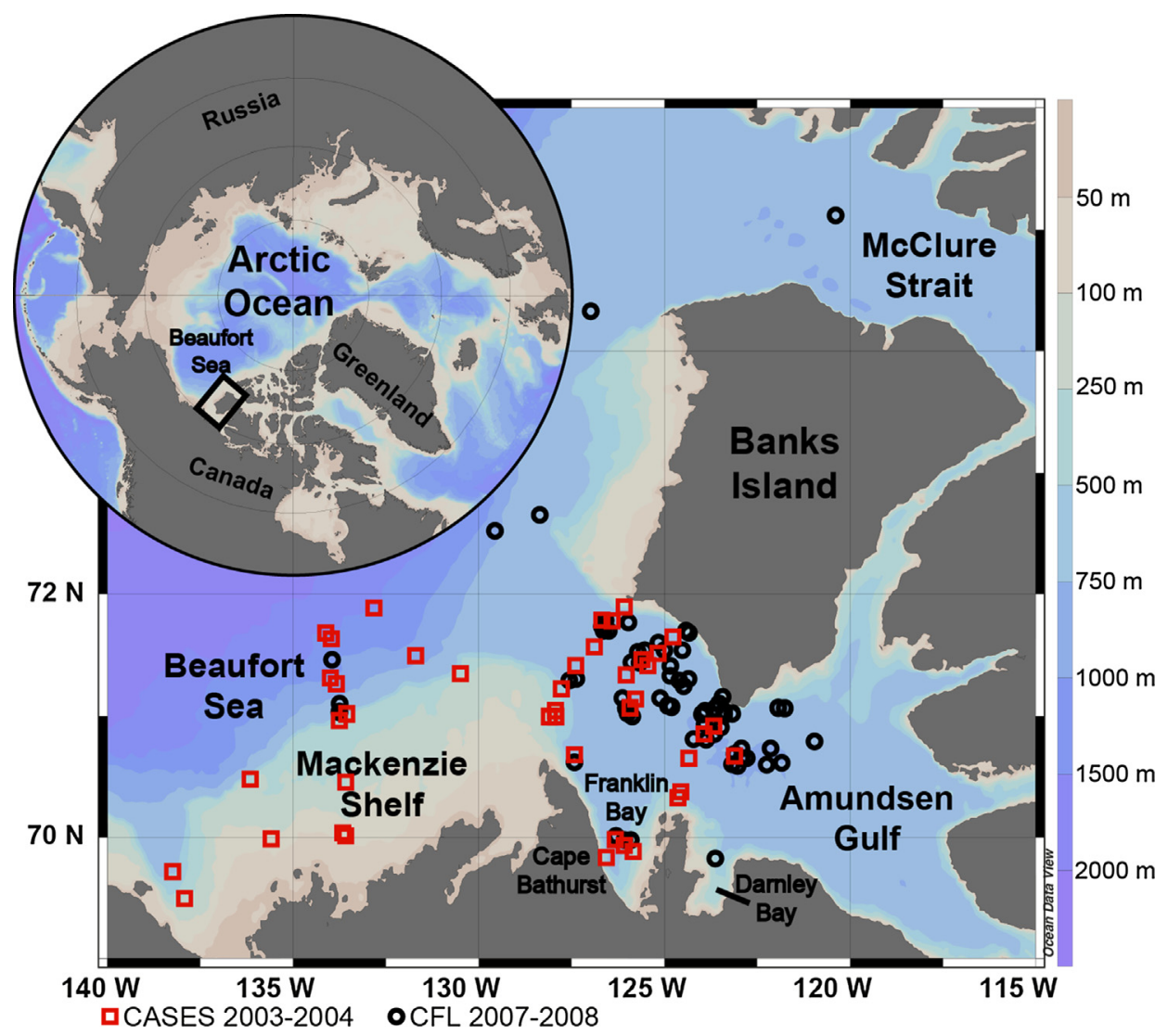

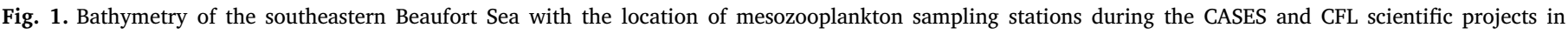
2003-2004 and 2007-2008, respectively. 
place at one fixed overwintering site in the landfast ice over Franklin Bay, contiguous to the south of Amundsen Gulf, from November 2003 to May 2004.

Zooplankton sampling procedures in $2007-2008$ as well as the characterization of environmental variables (sea-ice, temperature, salinity and pelagic chlorophyll $a$ (chl $a$ )) are detailed in Darnis and Fortier (2012). Wold et al. (2011) and Riedel et al. (2008) provided a description of ice-algae sampling and data on ice-algae concentration in 2008 and 2004, respectively. Prior to plankton net sampling, deployment of a rosette sampler fitted with a SBE911 plus ${ }^{\circledR}$ CTD and a Seapoint ${ }^{\circledast}$ fluorometer provided profiles of salinity, temperature and in situ fluorescence. In 2007-2008, the latter were calibrated using chl $a$ concentrations determined for water samples taken at discrete depths. In 2003-2004, data on fluorescence at $30 \mathrm{~m}$ depth was extracted from the study of Tremblay et al. (2008).

Depth-stratified samples for the assessment of zooplankton abundance were obtained by deploying a $0.50-\mathrm{m}^{2}$ aperture Hydrobios ${ }^{\circledR}$ multinet sampler carrying nine nets of $200 \mu \mathrm{m}$ mesh size, each fitted with a 2-L rigid codend. The sampler was hauled vertically from $10 \mathrm{~m}$ above the seafloor to the surface at a speed of $0.5 \mathrm{~m} \mathrm{~s}^{-1}$. Three $20-\mathrm{m}$ depth layers were sampled from $10 \mathrm{~m}$ off the bottom upward, and three from $60 \mathrm{~m}$ depth to the surface. The inconstant interval between $70 \mathrm{~m}$ above the seafloor and $60 \mathrm{~m}$ depth was divided in three equal sampling layers. The seasonal change in vertical distribution has already been described by Darnis and Fortier (2014), so this study focuses on abundance and biomass integrated over the water column. During the CASES program, mesozooplankton was sampled by vertical watercolumn integrated hauls at $0.5 \mathrm{~m} \mathrm{~s}^{-1}$, using the same multinet sampler and a $1 \mathrm{~m}^{2}$ square net (Darnis et al., 2008). Upon retrieval, each sample was preserved in a borax-buffered seawater solution of $4 \%$ formaldehyde for taxonomic identification.

In both years (2003-2004 and 2007-2008), live zooplankton for egg production experiments and biomass assessment were captured using a $1-\mathrm{m}^{2}$ square aperture vertical sampler with a $200-\mu \mathrm{m}$ mesh net and a 2 $\mathrm{L}$ rigid codend with filtration apertures located at the top of the cylinder. The net was towed vertically from $10 \mathrm{~m}$ above the bottom to the surface at $0.5 \mathrm{~m} \mathrm{~s}^{-1}$. Upon recovery, the plankton catch was diluted in $0{ }^{\circ} \mathrm{C}$ filtered seawater and cnidarians were immediately removed to reduce zooplankton mortality. The sample was kept at $0{ }^{\circ} \mathrm{C}$ until the Calanus hyperboreus copepodites were sorted in the laboratory. Attached to the main sampler, a $50-\mu \mathrm{m}$ mesh $1-\mathrm{m}$ long net of $81 \mathrm{~cm}^{2}$ mouth aperture sampled eggs and nauplii of Calanus spp. in 2007-2008 only (Supplementary Table 3). The samples were preserved in a boraxbuffered $4 \%$ formaldehyde solution.

\subsection{Taxonomic and biomass analyses}

The formalin-preserved samples were rinsed and size-fractionated on a $1000-\mu \mathrm{m}$ sieve before re-suspension in distilled water. Known aliquots were taken from the $200-1000$ and $>1000-\mu \mathrm{m}$ size fractions using a Henson-Stempel pipette and a Motoda splitting box, respectively, to collect from each fraction approximately 300 copepods that were enumerated, measured and identified to species, or to the lowest taxonomic level attainable. Young copepodite stages (CI-CIII) of $C$. hyperboreus and its congener C. glacialis were differentiated based on specific prosome lengths which differences were established during the CASES expedition (Forest et al., 2011a). The highly similar formalinpreserved eggs and naupliar stages of the two Calanus species were not differentiated during the taxonomic analysis. However, the time series of egg production experiments conducted simultaneously on C. hyperboreus and $C$. glacialis and $M$. longa indicated that $C$. glacialis did not start egg production before April. Thus, the Calanus eggs and nauplii found in the samples from January to late March were considered as $C$. hyperboreus. Copepodites IV-Adult of Metridia longa, C. glacialis, omnivore copepods such as Aetideidae, Euchaetidae and Heterorhabdidae, chaetognaths, cnidarians, and pelagic amphipods identified during the taxonomic analysis were counted in this study as potential predators of early developmental stages of $C$. hyperboreus.

The Calanus hyperboreus females incubated for egg production experiments were carefully blotted with absorbing material and preserved individually in cryovials at $-20^{\circ} \mathrm{C}$. On land, at least 10 of them were transferred to pre-weighed tin cups and oven-dried at $60^{\circ} \mathrm{C}$ for $48 \mathrm{~h}$ before dry weight (DW) measurement on a Sartorius ME5 ${ }^{\circledR}$ microbalance (precision $\pm 1 \mu \mathrm{g}$ ). A number of these tin cups were burned at $925^{\circ} \mathrm{C}$ in a Perkin Elmer CHN 2400 Series II Elemental Analyzer (accuracy, $0.3 \%$ and precision, $0.2 \%$ ) to measure the $\mathrm{C}$ content of the female copepods. An appropriate C:DW ratio was used to transform the other DW measurements to carbon content.

\subsection{Egg production}

Rapidly after capture, females in good condition were selected under a stereomicroscope by use of a truncated pipette, under dim light and at a temperature close to the in situ conditions $\left(0-0.5^{\circ} \mathrm{C}\right)$. Thirty of the randomly sorted females were individually placed in $45-\mathrm{mL}$ petri dishes, filled with $0.7-\mu \mathrm{m}$ filtered seawater and fitted with a false bottom (333- $\mu \mathrm{m}$ mesh) to prevent egg cannibalism. After incubation at $0{ }^{\circ} \mathrm{C}$ for $24 \mathrm{~h}$ in the dark, eggs were counted and the condition of the females verified prior to their preservation at $-20^{\circ} \mathrm{C}$ for future DW and $\mathrm{C}$ measurements. As most of the spawning occurred in the evening hours, with many of the shed eggs floating, verification for spawning was increased at that particular time to limit cannibalism on the eggs not protected by the false bottom.

\subsection{Lipid analysis}

Fatty acid composition of Calanus hyperboreus females collected from December to July throughout the water column were analysed at the Alfred Wegener Institute (AWI) in Bremerhaven. In the laboratory, total lipids were extracted according to the method of Folch et al. (1957), and then separated into polar and neutral lipids. Only the fatty acid composition of the neutral lipids is presented in this paper. See Wold et al. (2011) for detailed description of the fatty acid analyses.

\subsection{Statistical analyses}

Differences in C. hyperboreus abundance and female carbon content between the two annual cycles were tested using a nonparametric Wilcoxon-Mann-Whitney test with the software JMP 7. In 2003-2004, abundances in Amundsen Gulf (19 stations) were compared with abundances on the Mackenzie shelf-slope (19 stations), and in Franklin Bay (21 stations) to test for spatial variability in C. hyperboreus distribution over the study area.

A Spearman's rank-order correlation analysis using JMP 7 was done to assess the strength and direction of association between the integrated abundance (ind. $\mathrm{m}^{-2}$ ) of young stages of $C$. hyperboreus, from egg to CII, and potential zooplankton predators captured with the same $50-\mu \mathrm{m}$ mesh net over the period 21 January-05 May 2008. This period comprises the reproduction season of $C$. hyperboreus. A HolmBonferroni statistical correction was applied to the correlations to control the probability of a type I error with multiple comparison.

A principal component analysis (PCA) using CANOCO v4.5 (ter Braak and Šmilauer, 2002) was performed to reveal patterns in fatty acid composition of females from January to July 2008. Only the fatty acids contributing $>0.5 \%$ were considered, and the compositional fatty acid data were not transformed prior to analysis. Ordination techniques and rules of interpretation of PCA plots are summarized by ter Braak and Šmilauer (2002). In short, the closer the samples are clustered together, the more similar their fatty acid composition is. Projections of samples perpendicular to the fatty acid indicate their relative amount of these fatty acids. The fatty acids are standardized, centered and point in the direction of maximum change. The arrows of 
a)
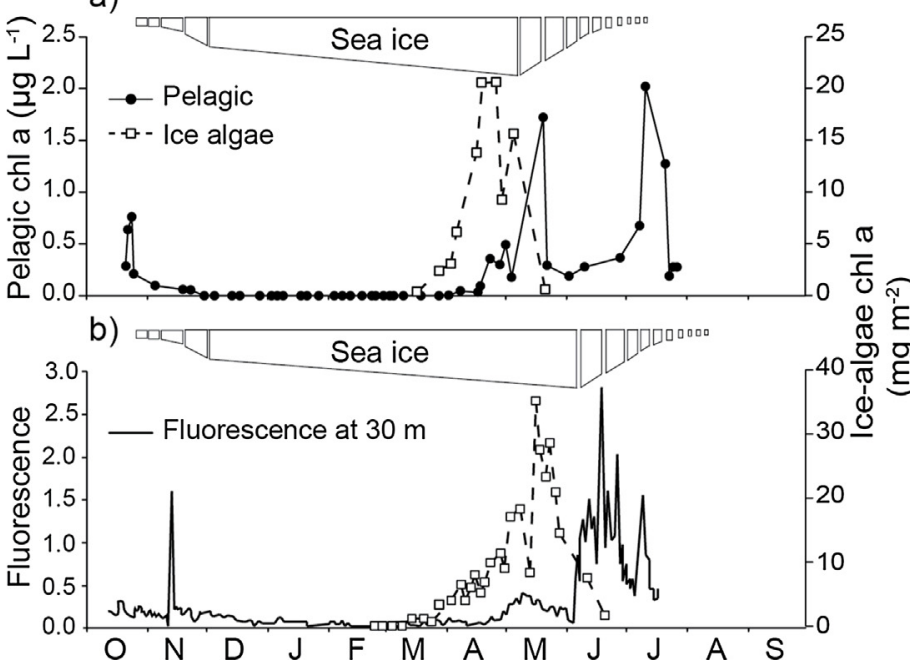


Fig. 2. Time series of (a) ice algae and pelagic chl $a$ concentration averaged over the 0-80 m surface layer in Amundsen Gulf from October 2007 to July 2008, (b) fluorescence (arbitrary unit) at $30 \mathrm{~m}$ depth at a mooring site in Franklin Bay and ice algae concentration at the CASES project overwintering site close to the mooring from October 2003 to July 2004, and (c) ice-algae mat at the undersurface of ice exposed to air. the fatty acids point in the direction of the steepest increase of the values for corresponding fatty acid, and the angles between arrows indicate the correlation between the fatty acids. The distance between the sample symbols approximates the dissimilarity of their fatty acid composition as measured by their Euclidean distance. The sample symbols can be projected perpendicularly onto the arrows of particular fatty acids. These projections can be used to approximate the values of that fatty acid in individual samples.

\section{Results}

\subsection{Sea ice and chlorophyll}

In late October 2007, the ice cover was rapidly forming in Amundsen Gulf and ice consolidation was completed by December (Fig. 2a). By mid-March 2008, ice-algae mats started to build up rapidly in the lowermost $3 \mathrm{~cm}$ of the ice (Fig. 2a) and reached highest biomass (20 $\mathrm{mg}$ chl $a \mathrm{~m}^{-2}$ ) between mid-April and early May, after which the rapid ice-breakup prevented any further ice-algae development. In 2003, the ice cover was rapidly forming in early October in Franklin Bay (Fig. 2b). In 2004, ice algae concentration started to increase in mid-March, as in 2008. However, the maximum biomass ( $>35 \mathrm{mg}$ chl $a \mathrm{~m}^{-2}$ ) was reached approximately two to three weeks later than in 2008.

In late October 2007, chl a concentrations, averaged over the $0-80 \mathrm{~m}$ surface layer, nearly reached $1 \mu \mathrm{g} \mathrm{L}{ }^{-1}$; but the rapid decline of photosynthetically active radiations and expansion of ice drove fluorescence close to nil values from November to the first records in late April 2008 of concentrations above $0.1 \mu \mathrm{g} \mathrm{L}^{-1}$ under the ice (Fig. 2a). A first pelagic microalgal bloom (chl $a>1.5 \mu \mathrm{g} \mathrm{L}^{-1}$ ) was recorded in mid-May in the central Amundsen Gulf once the ice cover went below the $50 \%$ threshold. Following this high primary production event, a period of relatively low fluorescence ( $<0.5 \mu \mathrm{g} \mathrm{chl} a \mathrm{~L}^{-1}$ ) in the $0-80 \mathrm{~m}$ layer lasted the entire month of June before the development of strong subsurface chl $a$ maximum in July. In 2004, non-negligible fluorescence started to be measured at $30 \mathrm{~m}$ depth in early May (Fig. 2b). The first peak in fluorescence, indicative of a pelagic bloom, occurred at ice breakup in mid-June, one month later than in 2008.

\subsection{Abundance and ontogenesis of Calanus hyperboreus}

Integrated abundances of Calanus hyperboreus copepodites did not show any apparent seasonal pattern in 2007-2008 and in 2003-2004 (Fig. 3a and b), and averaged similar values over the two quasi-annual cycles, with $2015 \pm 1573$ and $1981 \pm 2192$ ind. $\mathrm{m}^{-2}$, respectively
(Fig. 4). The same can be said of the adult females, with $600 \pm 466$ ind. $\mathrm{m}^{-2}$ in $2007-2008$, and $639 \pm 706$ ind. $\mathrm{m}^{-2}$ in 2003-2004 (Fig. 4). Restricting the observation to the winter period from early January to late April, abundances of adult females were also similar in 2008 and 2004, with $742 \pm 459$ ind. $\mathrm{m}^{-2}$ and $744 \pm 262$, respectively. In 2008, copepodite abundances $>6000$ ind. $\mathrm{m}^{-2}$ in late May and early July were recorded at two relatively deep stations ( $>350 \mathrm{~m}$ ) off the northwest coast of Banks Island and in McClure Strait (CF83 and CF94 in Fig. 3a; Table 1). High numbers of CI in May, and CII in July, were responsible for these peaks. In July 2004, the highest abundances ( $>7000$ ind. $\mathrm{m}^{-2}$ ) were recorded at two $>250 \mathrm{~m}$ depth stations (CA68 and CA76 in Fig. 3b; Table 2) on the Mackenzie slope and in Amundsen Gulf further east, and CIII and CV dominated the copepodite population at these two stations, respectively.

The copepodite abundance over the period 2003-2004 (Fig. 4) was lower on the Mackenzie shelf-slope (median 876 ind. $\mathrm{m}^{-2}$ ) than in Franklin Bay (2033 ind. $\mathrm{m}^{-2}$; Wilcoxon-Mann-Whitney; $\mathrm{p}=0.025$ ). However, there was no difference between the abundance in Franklin Bay and in Amundsen Gulf (median 2007 ind. $\mathrm{m}^{-2}$ ). The female abundances followed the same pattern, with median values of 271, 588 and 752 ind. $\mathrm{m}^{-2}$ in the Mackenzie shelf-slope area, Franklin Bay and Amundsen Gulf, respectively (Wilcoxon-Mann-Whitney; $p=0.033$ ).

The copepodite stage composition and seasonal dynamics were also similar between the two years. The main overwintering stages were CIV (41 and 40\% from October to April 2007-2008 and 2003-2004, respectively), adult females (AF) (34 and 36\% for the same periods), and to a lesser extent CV (13 and 15\%) and CIII (8 and 7\%) (Fig. 3c and d). They were present year-round in Amundsen Gulf but their importance showed different seasonal fluctuations. An increase in CV contribution occurred alongside a steep decrease in CIV in May and early June, and then recruitment of CIV resumed in July. The proportion of overwintering $\mathrm{CV}$ decreased over the winter period. The AF share reached almost $50 \%$ of the population in March-April. Female contribution remained above $20 \%$, except in late May 2008 off the western coast of Banks Island, and in late June-early July 2008 and 2004 on the Mackenzie shelf and slope. Males were present from late October 2007 and 2003 to early June 2008 and mid-March 2004 in low numbers, and male:female ratios $>0.2$ were only found from November to January. In 2008, the first significant cohort of CI (13\% of the population) appeared on 22 May in Amundsen Gulf whereas massive recruitment of CI ( $>75 \%$ ) was only observed on 26 and 27 May off the western coast of Banks Island and this stage never dominated in Amundsen Gulf. About one month later, stage CII led the population only at two shallow sites $(\sim 200 \mathrm{~m})$ at the periphery of Amundsen Gulf (near Cape Bathurst and the southwest coast of Banks Island, respectively) and in McClure Strait. 


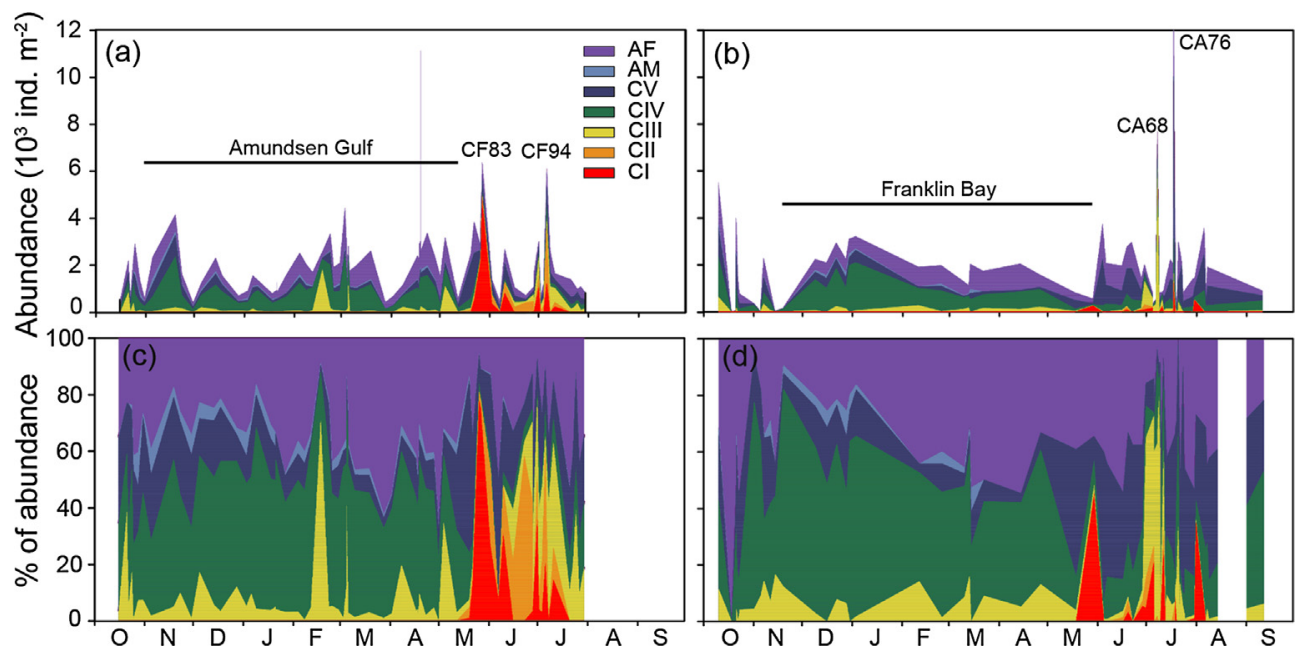

Fig. 3. Seasonal change in abundance, and numerical composition of Calanus hyperboreus in the southeastern Beaufort Sea during the annual cycles 2007-2008 (a, c) and 2003-2004 (b, d). Identification of peaks (a, b) refers to stations identification numbers in Tables 1 and 2, respectively.



Fig. 4. Maps of water column integrated abundance of Calanus hyperboreus copepodite population (top maps) and adult females (AF; bottom maps) in the southeastern Beaufort Sea over the annual cycles 2003-2004 and 2007-2008. Grey contours in top left map delimit areas of the Mackenzie shelf, Amundsen Gulf and Franklin Bay, respectively, used in the analysis of spatial variability in abundance.

By mid-July young stages CI-CII were found no more. In 2004, CI appeared also in late May under the sea ice of Franklin Bay at the southern border of Amundsen Gulf, and then they occurred sporadically at the following stations on the Mackenzie shelf and Amundsen Gulf where they were never dominant ( $0-35 \%$ of the copepodite population). Likewise, CII were not present at all stations in 2004, and contributed little $(0.7-11 \%)$ to the copepodite population from mid-June to midJuly, when they were present.

\subsection{Reproduction}

In Amundsen Gulf, Calanus hyperboreus reproductive season
Table 1

Spearman's rank-correlation coefficients $\left(\mathrm{r}_{\mathrm{s}}\right.$; significance level * < 0.016) between water column integrated abundance of young stages of Calanus hyperboreus (egg-CII) and their potential predators, all zooplankton estimated from vertical tows using a $50-\mu \mathrm{m}$ mesh net in the southeastern Beaufort Sea in 2008.

\begin{tabular}{llll}
\hline $\begin{array}{l}\text { Calanus hyperboreus } \\
\text { stage }\end{array}$ & $\begin{array}{l}\text { Metridia longa } \\
\text { CIV-Adult }\end{array}$ & $\begin{array}{l}\text { Calanus glacialis } \\
\text { CIV-Adult }\end{array}$ & Other predators \\
\hline Egg & $0.305^{*}$ & 0.117 & -0.067 \\
N1 & $0.294^{*}$ & 0.197 & 0.009 \\
N2 & 0.254 & 0.129 & -0.177 \\
N3 & $0.329^{*}$ & -0.009 & 0.007 \\
N4 & 0.034 & 0.028 & 0.268 \\
N5 & -0.200 & 0.121 & 0.189 \\
N6 & -0.044 & 0.121 & 0.026 \\
CI & -0.125 & 0.019 & -0.167 \\
CII & -0.144 & -0.112 & -0.014 \\
\hline
\end{tabular}

extended from mid-January to mid-April (Fig. 5) before any sizeable chl $a$ concentration would be measured in the surface layer. A similar timing of reproduction was found in Franklin Bay, as the first spawning females spawned a small clutch (26 eggs) in late December 2003, and the last in late April 2004 (Fig. 5a). However, the egg production rates were higher in $2008\left(31 \pm 17\right.$ eggs $\mathrm{f}^{-1} \mathrm{~d}^{-1}$, averaged over the reproduction season) than in $2004\left(14 \pm 10\right.$ eggs $\left.\mathrm{f}^{-1} \mathrm{~d}^{-1}\right)$. Daily egg production rates were highly variable, ranging between 7 and 65 eggs $\mathrm{f}^{-1} \mathrm{~d}^{-1}$, or 20-65 eggs $\mathrm{f}^{-1} \mathrm{~d}^{-1}$ when just the peak February-March production period is considered in 2008 (Fig. 5a). High variability was also seen in the clutch size in most of the experiments throughout the season in 2008 and 2004 (Fig. 5b). Mean clutch size ranged between 65 and 194 eggs in 2008 and 26 and 165 eggs in 2004 without any obvious temporal pattern. Maximum clutches of 404 and 333 eggs were counted in late February 2008 and mid-March 2004, respectively. At the start of reproduction in mid-January, the proportion of spawning females increased steeply from 3\% to 33\% in a two-week time in 2008 (Fig. 5c). A swift decrease in the spawning frequency occurred in late March at the end of the reproductive season, right after the record $40 \%$ of spawning females in the population was measured. The January-February hiatus in the egg production data prevents tracking the early stage of the reproduction season in 2004. However, the end of the reproduction season occurred about the same time as in 2008 (Fig. 5a). On the other hand, the decrease in frequency of spawning females seemed to have occurred a few weeks earlier in 2004 than in 2008, and the maximum of $31 \%$ of spawning females in late February was one month earlier (Fig. 5c). 


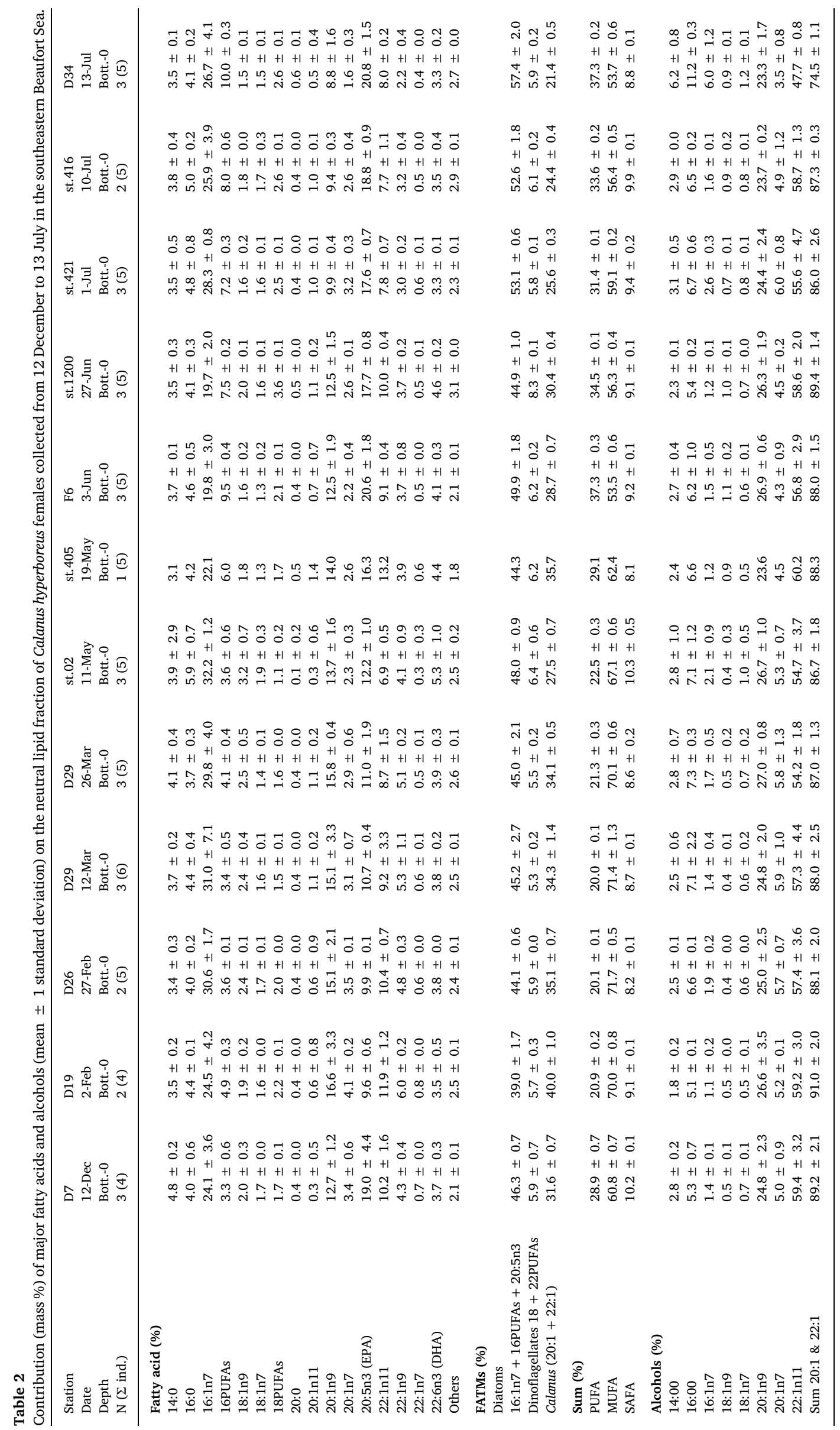




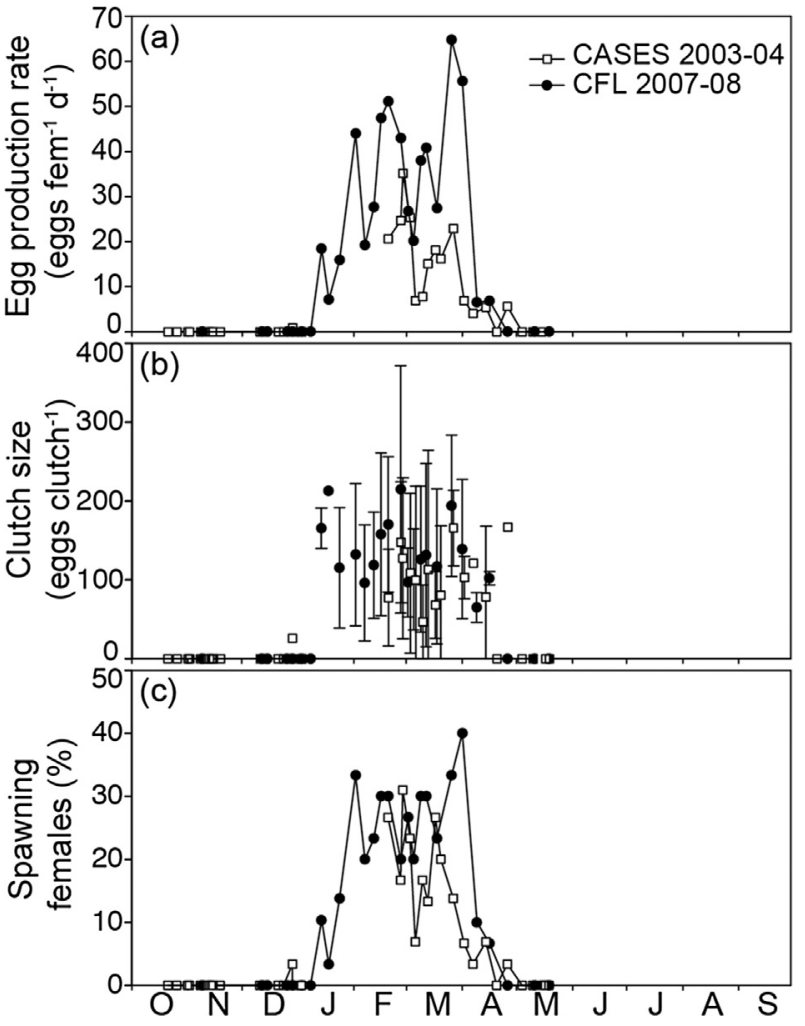

Fig. 5. Time series of egg production rate (EPR) in Amundsen Gulf in 2007-2008 and Franklin Bay in 2003-2004 (a), clutch size ( \pm 1 standard deviation) (b), and proportion of spawning females (c).

In 2008, daily egg production by the population (individual egg production rate $\times$ density of females) increased rapidly from 0 in early January to $35848 \pm 12868$ eggs $\mathrm{m}^{-2} \mathrm{~d}^{-1}$ in early February (Fig. 6a)

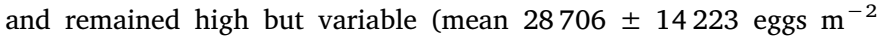
$\mathrm{d}^{-1}$ ) throughout the February-March period of intense individual egg production rates. A steep decrease occurred from mid-March to early April.

A period of high abundance of $C$. hyperboreus eggs coincided with the peak reproduction phase in February-March during which an average $28863 \pm 23310$ eggs $\mathrm{m}^{-2}$ were distributed in the water column of Amundsen Gulf (Figs. 5a and 6b). Nauplii became most abundant in early March and were composed essentially of stages N1 to N3 (Fig. 6c). Their abundance decreased dramatically to $<6000$ ind. $\mathrm{m}^{-2}$ in mid-April. The first N4, N5 and N6 appeared in mid- and late April, and late May, respectively. The second peak in nauplii, in late April-early May, was dominated by N1 and N3. Most of the N3 were then likely $C$. hyperboreus. However from then on, the naupliar stages might have been a mix of the two Calanus species.

\subsection{Seasonal variability of adult females carbon content}

From October 2007 to the end of February 2008, the individual carbon content of adult females showed no particular trend and averaged $2.9 \pm 0.42 \mathrm{mg} \mathrm{C}$ (Fig. 7). By early March, in the middle of their reproductive season, the mass of females had decreased considerably and this decline continued until mid-April, when the lowest carbon content of $1.34 \pm 0.42 \mathrm{mg} \mathrm{C} \mathrm{f}^{-1}$ was recorded. At the onset of the phytoplankton bloom in May, females carbon content started to increase and, within three months, reached values in excess of $3.75 \pm 0.59 \mathrm{mg} \mathrm{C}$, representing a 2.8-fold increase from the April lowest values. In 2003 in Franklin Bay, the carbon content of adult females averaged $2.44 \pm 0.41 \mathrm{mg} \mathrm{C}$ and was not statistically different from the mean carbon content measured in 2007 (Wilcoxon-Mann-
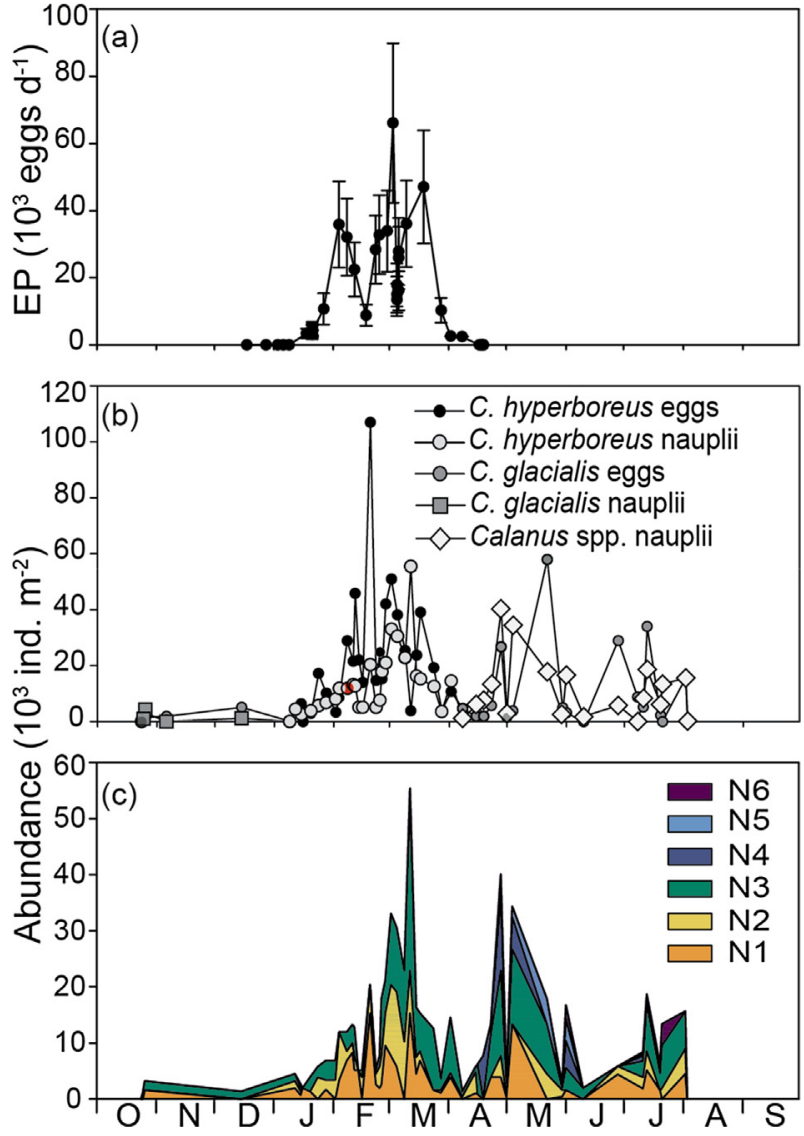

Fig. 6. Time series of the population egg production rates of Calanus hyperboreus (a), water column total abundance of eggs and nauplii of C. glacialis, C. hyperboreus and Calanus spp. at stations $>250 \mathrm{~m}$ depth within Amundsen Gulf (b), and abundance of each nauplius stage (c).

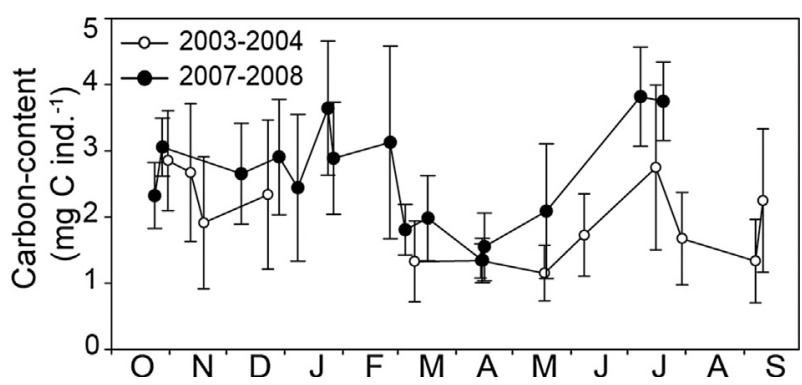

Fig. 7. Time series of carbon-content ( \pm 1 standard deviation) of Calanus hyperboreus adult females captured in Amundsen Gulf in 2007-2008 and in Franklin Bay in 2003-2004.

Whitney; $\mathrm{p}=0.1244$ ) due to the large variability in the body condition of females at any given site (Fig. 7). Low-carbon females $(1.33 \pm 0.61 \mathrm{mg} \mathrm{C})$ were already found in early March, although earlier occurrence of females with poor body condition cannot be excluded since there is a gap in the dataset extending from early January 2004 to early March 2004. As of May, their carbon content more than doubled within two months to reach $2.75 \pm 1.25 \mathrm{mg} \mathrm{C}$.

\subsection{Potential predators of Calanus eggs and naupliar stages}

Copepodites IV-Adult of $M$. longa and $C$. glacialis dominated largely the selected potential zooplankton predators throughout the two years, contributing $60-97 \%$ and $23-99 \%$ of the assemblage in $2007-2008$ and 2003-2004, respectively (Fig. 8a and b). A clear increase in the 




Fig. 8. Seasonal change in abundance of potential predators of eggs and naupliar stages of Calanus hyperboreus during the CFL 2007-2008 (a) and CASES 2003-2004 annual cycles (b) in the southeastern Beaufort Sea.

potential predators in late January 2008 (Fig. 8a) was mainly due to higher abundance of $C$. glacialis, followed by $M$. longa, and coincided with the beginning of substantial egg production by $C$. hyperboreus. This period of higher abundance lasted until late April and covered the entire reproduction period of $C$. hyperboreus. Metridia longa became the dominant potential predator by mid-February, representing $43-67 \%$ of the assemblage at the peak period of $C$. hyperboreus reproduction. Contrary to 2008, there was no increase in the potential predators during the reproduction season of C. hyperboreus in winter 2004 (Fig. 8b).

Overall, Metridia longa and C. glacialis CIV-Adult were approximately 3 times more abundant in the southeastern Beaufort Sea in 2008 than in 2004, whereas the sum of other potential predators was slightly less than 2 times higher in 2008 than in 2004 (Fig. 9). The highest abundances of all groups were generally found in Amundsen Gulf.

After statistical correction using the Holm-Bonferroni method, integrated abundance of Calanus hyperboreus eggs and nauplii N1 and N3 were positively correlated to the abundance of stages CIV-Adult of Metridia longa (Table 1). There was no correlation between any of the young stages of $C$. hyperboreus and $C$. glacialis CIV-Adult or the group of other predators including Aetideidae, Euchaetidae and Heterorhabdidae, chaetognaths, cnidarians, and pelagic amphipods.

\subsection{Seasonal fatty acid composition of females}

The proportion of mono- and polyunsaturated fatty acid (MUFA and PUFA) diatom markers (16:1n7, 16PUFAs and 20:5n3) in the neutral lipid fraction of Calanus hyperboreus females was between 39 and 46\% in winter (Table 2). It increased in spring and summer, reaching a maximum of $57 \%$ in July. The dinoflagellate markers (18 PUFAs and $22: 6 n 3)$ contributed 5-6\% during the entire sampling period, except in late June when they reached $8 \%$. The highest level of the typical $\mathrm{Ca}$ lanus long-chained MUFAs and fatty alcohols 20:1 and 22:1 was found during winter (32-40\%) and decreased to $21 \%$ in July. In contrast, the 16PUFAs and $20: 5 \mathrm{n} 3$ diatom markers increased from 20 to $21 \%$ in winter to $31-37 \%$ in June and July. The long-chained MUFAs 22:1 and 20:1 made up the largest fraction of the fatty alcohols (75-91\%) with the highest level in February and the lowest in July. The two first axis of the PCA (Fig. 10) explained $91 \%$ of the total variance in the fatty acid composition and PCA confirms the difference in fatty acid composition according to season, with a few exceptions. The only sample from late autumn/early winter (12 Dec) was not linked with any of the other samples. The winter samples (2 Feb-26 March) were not closely

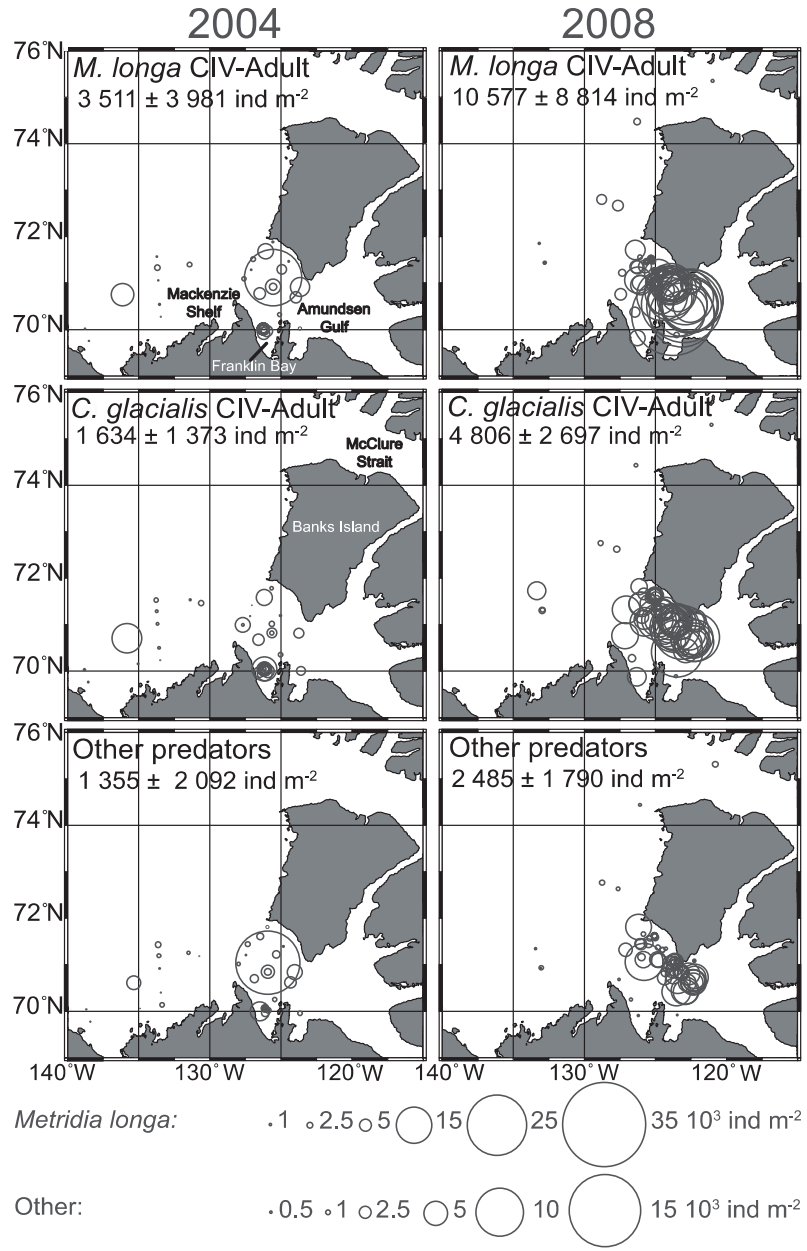

Fig. 9. Maps of water column integrated abundance of Metridia longa and Calanus glacialis CIV-Adults and other potential zooplankton predators (large omnivore and carnivore copepods, chaetognaths, cnidarians, and amphipods) in the southeastern Beaufort Sea in 2004 and 2008.

grouped together. However, they are distributed at the right side of axis 1 in the same direction as the Calanus markers 20:1 and 22:1 as well as 18:1n9. The sample indicative of the pre-bloom period (11 May) is also located to the right side, as the winter samples, while the samples from the spring bloom (19 May-27 June) are grouped together. The last dates are linked with the diatom markers 20:5n3, 16 PUFAs, as well as the dinoflagellate marker 18 PUFA. The samples from the summer grouped together and are also connected with the diatom markers 20:5n 3 and 16 PUFAs but they have a higher contribution of $24: 1 \mathrm{n} 9$ than the spring bloom samples.

\section{Discussion}

Following the record low sea-ice extent of autumn 2007 over the Amerasian Arctic Ocean (NSIDC, 2010), the ice cover in 2008 in Amundsen Gulf receded rapidly from early May onward, initiating the pelagic bloom about one month earlier than usual (Galley et al., 2008). Total gross primary production, estimated from nutrient drawdown over spring-summer 2008 was about $80 \%$ higher than during the CASES program in 2004 (Forest et al., 2011b), a year of average ice concentrations and less dynamic ice cover (Galley et al., 2008). Our two quasi-annual time series characterised by different environmental conditions appear, thus, as a useful dataset to study how changes in the timing of primary production may affect recruitment in the population of Calanus hyperboreus and influence some of its life history traits. The low proportion of young copepodites CI and CII in early summer and 


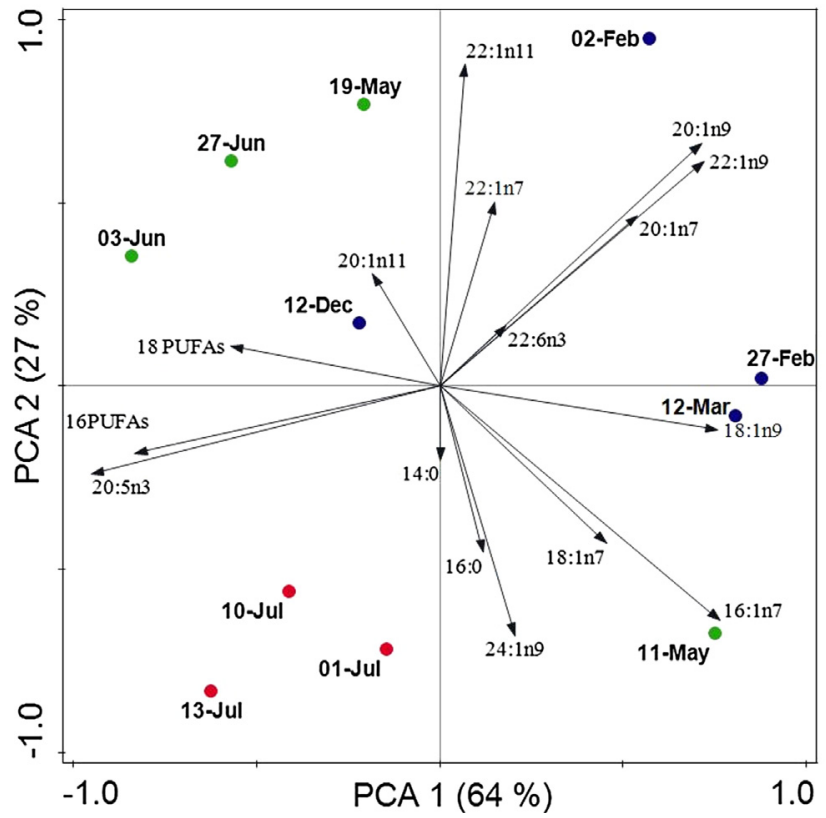

Fig. 10. Principal component analysis (PCA) of the fatty acid composition of neutral lipid fraction of Calanus hyperboreus females in southeastern Beaufort Sea from December 2007 to July 2008. The different colors indicate the season: black $=$ early winter; blue $=$ winter, green $=$ spring; red $=$ summer. (For interpretation of the references to colour in this figure legend, the reader is referred to the web version of this article.)

reduced overall abundance later in the season suggest poor recruitment to copepodite stage in the $C$. hyperboreus population in the southeastern Beaufort Sea in 2004. Unexpectedly, a similar picture can be drawn for this population at the end of the CFL study in summer 2008 despite the relaxed environmental conditions that year. Spatial variability should be considered when comparing the situation of $C$. hyperboreus in 2004 and 2008 , as winter stations were sampled in different, although adjacent, areas of the southeastern Beaufort Sea in the two years. Spatial variability in zooplankton abundances is well illustrated in Figs. 4 and 9. Interestingly, the number of spawning females was about the same in the two overwintering areas-years, indicating that location had likely little effect on the $C$. hyperboreus reproductive stock. Furthermore, Benoit et al. (2008) showed that oceanographic processes transport schools of Arctic cod, and undoubtedly zooplankton, from Amundsen Gulf to Franklin Bay where the overwintering site was located in 2004. However, abundance of large omnivore and carnivore zooplankton tended to be higher in Amundsen Gulf than in surrounding areas in 2008. Based on one of the most thorough analysis of $C$. hyperboreus life cycle and winter reproduction, supported by ancillary data on the environment and demography of other pelagic taxa, we propose that a top-down control by other zooplankton on the early stages of $C$. hyperboreus explains to a large extent the low recruitment in 2008 in the population of this key species of the Arctic marine food web.

\subsection{Life cycle of Calanus hyperboreus in the southeastern Beaufort Sea}

In Amundsen Gulf, the overwintering Calanus hyperboreus population remained stable throughout the period October-April during which it comprised predominantly copepodite stages CIV and adult females. The simultaneous presence of several overwintering stages is indicative of a multi-annual life cycle in arctic seas and in the northwest Atlantic (Conover, 1988; Hirche, 1997; Plourde et al., 2003). With CIV as the primary overwintering stage, we propose a 2- to 3-year life cycle in the region. This life cycle is in good agreement with those reported for areas characterized by a relatively long open-water season of biological production, such as the eastern North Water polynya (Ringuette et al.,
2002), the south-western Greenland coast (Madsen et al., 2001; Swalethorp et al., 2011), the Atlantic water of the West Spitsbergen Current (Hirche, 1997), and the lower St-Lawrence Estuary further south (Plourde et al., 2003). A life cycle of at least 3 years was proposed, based on the dominance of stage CIII in the overwintering population, over the heavily ice-covered central Arctic Basin (Dawson, 1978), Resolute Passage in the Canadian Arctic archipelago (Conover, 1988), but also in the more ice-free Central Greenland Sea Gyre (Hirche, 1997). Conover and Siferd (1993) suggested also a 3- to 4-year life cycle in Barrow Strait although CIV was the prevalent overwintering stage in the winters of 1984 and 1985 . They doubted that this late developmental stage could be achieved in a single and usually short growth season (2.5 and 3 months in 1984 and 1985, respectively) in this sector of the Canadian Arctic archipelago. However, this was likely not the case in Amundsen Gulf in 2008 as the precocious onset of the ice break-up extended the potential growth season to $>5$ months and would have allowed the young $C$. hyperboreus to develop to stage CIV.

The Arctic Calanus species are lipid-rich animals, increasing their reserves during the ice algae and phytoplankton blooms (Falk-Petersen et al., 2009). During 2008 overwintering stages CIV took advantage of the large supply of diatoms in May (Forest et al., 2011b) to grow and rapidly molt into stages $\mathrm{CV}$, similar to what has been observed in the Greenland Sea (Hirche 1997). Adult females were among the first to ascend to the surface in late April (Darnis and Fortier, 2014), approximately two weeks before ice break-up and the intense first phytoplankton bloom. The rather large proportion of females in the overwintering population migrating upward (27-66\%) lends support to the possibility of reproduction over multiple seasons (iteroparity), as suggested by Conover and Siferd (1993) and Hirche (1997, 2013). A multiannual life cycle and iteroparity would be a favourable combination of adaptations for $C$. hyperboreus to dampen the effects of unsuccessful reproductive years. Within two months in the upper part of the water column in 2008 , the females nearly tripled their carbon content from the minimum values attained in mid-April. The timing of increase of typical diatom fatty acids (16:1n7, 16 PUFAs and EPA) during spring indicates that females were feeding first on the ice algae and later on the phytoplankton production. Accumulation of long-chained fatty acids, such as 20:1 and 22:1 characteristic of storage lipids, from May to July is in line with a substantial increase in their lipid reserves. Sufficient food during the phytoplankton bloom had enabled the females to quickly fill their reserves. A seasonal downward migration was observed already at the end of July despite a strong sub-surface chlorophyll maximum (SCM) (Darnis and Fortier, 2014), indicating that females C. hyperboreus had accumulated enough lipid reserves for overwintering. Levels of storage MUFAs 20:1 and 22:1 and PUFAs are within the range of those reported from Cumberland Sound for both summer and winter (McMeans et al., 2012). However, females fatty acid composition in Amundsen Gulf in summer differed from that of CVfemales in Kongsfjorden (Svalbard) in September, which had less PUFAs and more 20:1 and 22:1 (Scott et al., 2002), and in Northern Baffin Bay in September-October with higher levels of EPA and 16:1n7 but lower MUFAs 20:1 + 22:1 (Stevens et al., 2004). Phenology and species composition of the protist community are likely explanations for the difference in fatty acid composition among the different studies. Significant development of CII into CIII and CIII into CIV started in midJune and early July, respectively. No sign of downward migration by these stages in late July, in contrast with adult females (Darnis and Fortier, 2014), suggests that they remained close to the SCM to continue feeding in the late summer. Thus, the stages CI and CII that first appeared in the surface layer in May were presumably capable of achieving development to stage CIV in 2008 before migrating to depth for the overwintering period, like the scenario of a 2- to 3-year life cycle implies for this species in the region. As suggested by Hirche (1997), continuous decrease of $\mathrm{CV}$ contribution to the overwintering population was likely due to their molting into adult stages. It is not certain that these new adult females take part in the winter reproduction that 
requires substantial metabolic energy. Interestingly, the period of adult males occurrence in the overwintering population was much longer in 2007-2008 than in 2003-2004. Better feeding conditions and ensuing lipid deposition in 2007 for $\mathrm{CV}$, like the case of adult females suggests (Fig. 7), might explain this discrepancy.

Timing of copepodite recruitment in May (i.e. appearance of the first stages CI in the population) and apparent match between new CI and high phytoplankton new production were similar to those reported for the eastern North Water polynya and Disko Bay, two regions that witness an earlier onset (by 1-2 months) of the phytoplankton bloom than the southeastern Beaufort Sea (Madsen et al., 2001; Ringuette et al., 2002). The relationship between timing of the bloom and of CI recruitment observed in Amundsen Gulf and in other sectors over the extensive geographical range of Calanus hyperboreus (Ringuette et al., 2002), supports the assumption of a specific adaptation of the spawning strategy of this species to ensure that first-feeding naupliar stages appear with the onset of pelagic primary production (Conover and Huntley, 1991). This approach should maximize growth, development to overwintering stages and lipid storage during a summer season of often brief but intense pelagic primary production.

\subsection{Reproduction}

Our two time-series of egg production rates for 2003-2004 and 2007-2008 indicate that the reproductive season of Calanus hyperboreus lasts from January to mid-April in the southeastern Beaufort Sea. The prime mating period would be from November to January when the male:female ratio reaches its highest. Such timing of reproduction is similar to those reported for the central Arctic Ocean (January-May) (Johnson, 1963), Disko Bay (February-mid-April) (Niehoff et al., 2002) and the Lower St. Lawrence Estuary (January-late March) (Plourde et al., 2003). However, reproduction is delayed until between midMarch and May in the Canadian Arctic archipelago (Conover and Siferd, 1993), and between May and June in Foxe Basin (Grainger, 1965), two areas with typically late ice break-up. By contrast, in the central Greenland Sea experiencing a much more sporadic ice cover, reproduction season extends from November to late March/April (Hirche and Niehoff, 1996). Lack of repeated sampling over several winters precludes any assessment of interannual variation in these regions. Nevertheless, the reproductive cycle was completed while the females were at depth, experiencing a fairly stable ambient temperature, and before any sizeable primary production were measured in the surface layer (Darnis and Fortier, 2014). Decreasing storage fatty acids during reproduction further confirms that Calanus hyperboreus females fuel their egg production solely with their lipid reserves (Hirche and Niehoff, 1996). The reproductive strategy (capital breeding, timing and duration) of this species is thus independent of the in situ environmental setting, but most likely results from local adaptation and acclimatization to variability in food supply for the offspring, as well as body condition and physiology of the females in the preceding year (Conover and Siferd, 1993; Hirche and Niehoff, 1996; Varpe, 2012).

Individual egg production rate averaged over the reproductive season (31 eggs $\mathrm{f}^{-1} \mathrm{~d}^{-1}$ ) in Amundsen Gulf in 2008 exceeded those for February-March in neighbouring Franklin Bay in 2004 (19 eggs $\mathrm{f}^{-1}$ $\mathrm{d}^{-1}$ ) and in Greenland Sea (9 eggs $\mathrm{f}^{-1} \mathrm{~d}^{-1}$ ) (Hirche and Niehoff, 1996). It is similar to the single estimate of 33 eggs $\mathrm{f}^{-1} \mathrm{~d}^{-1}$ made in Disko Bay in mid-March 1997 (Madsen et al., 2001). Furthermore, egg production rates, ranging 7-65 eggs $\mathrm{f}^{-1} \mathrm{~d}^{-1}$, between February and early April 2008 compare well with the $4-54$ eggs $\mathrm{f}^{-1} \mathrm{~d}^{-1}$ produced at the same period in Disko Bay in 2009 (Henriksen et al., 2012) despite the fact that we used much smaller incubation chambers than Henriksen et al. (2012). Our experimental setup may have made the egg counts conservative due to the higher risk of egg consumption by the spawning females in a smaller chamber. However, the individual egg production estimates of the present study are the highest of all published estimates found. The frequent verification for spawning events in the evenings surely helped reduce cannibalism on floating eggs but the use of an experimental setup to deal better with the floating eggs would need to be developed for future measurements. The higher individual egg production in Amundsen Gulf in 2008 relative to Franklin Bay in 2004 could reflect a better growth season for the stages $\mathrm{CV}$ and adult females in the early summer of 2007 than in 2003 . However, data on the body condition of most of the 2004 spawning females is lacking to support this assumption. Nevertheless, based on their carbon content, it is obvious that the females had better feeding conditions in spring-summer 2008 than in 2004.

\subsection{Control of recruitment}

Recruitment of stages CI coincided with the onset of an intense phytoplankton bloom in May 2008. However, new CI contributed only $13 \%$ to the population, suggesting that recruitment in Amundsen Gulf was modest compared to sites off the western coast of Banks Island and in M'Clure strait where CI represented $>75 \%$ of the copepodites in late May 2008. Stagnation of population growth from May to July further supports the assumption of poor copepodite recruitment in Amundsen Gulf in 2008 since the reproduction season was over by early April and no additional CI recruits could thus be expected after July. In FebruaryMarch, high total egg production rates and relatively high abundances of eggs and young nauplii N2-N3 in the water column indicated that $C$. hyperboreus had indeed a vigorous winter 2008 reproduction.

Nauplius stage N3 is the first feeding stage of $C$. hyperboreus (JungMadsen et al., 2013). Since most eggs and newly hatched nauplii float toward the surface waters (Conover and Huntley, 1991), they experience temperatures ranging from $0{ }^{\circ} \mathrm{C}$ in the Atlantic layer to $-1.7^{\circ} \mathrm{C}$ in the PML during ascent. Egg ascent rates are highly variable $(0.7-27.7 \mathrm{~m}$ $\mathrm{d}^{-1}$ ) (Jung-Madsen et al., 2013). Furthermore, numerous non-feeding nauplii N1-N2 were caught in sediment traps at $200 \mathrm{~m}$ depth in central Amundsen Gulf in winter 2004, indicating that ascent is not necessarily immediate (Ota et al., 2008). Applying the upper range of winter temperatures to a Belehrádek's function (Ji et al., 2012) gives approximately 40 days for a $C$. hyperboreus egg to develop to N3 at $0{ }^{\circ} \mathrm{C}$. Thus, eggs spawned in late February right at the egg production peak would have developed to first feeding stage in mid-April when ice-algae stocks were at their maximum and chl $a$ concentrations in the surface layer started to be recorded again, although at low levels $\left(<0.5 \mu \mathrm{g} \mathrm{L}^{-1}\right)$. Naupliar stages of calanids can sustain high growth rates at low food concentrations limiting to the late copepodite stages (Hygum et al., 2000; Richardson and Verheye, 1999). Calanus nauplii are mainly herbivores (Campbell et al., 2009; Forest et al., 2011a) taking advantage of diatom cells eroded from the ice at the peak of icealgae production in April. The subsequent onset of the pelagic bloom would have also provided favourable feeding conditions for the nauplii that hatched from eggs spawned throughout March. Thus, we surmise that nauplii from the large numbers of eggs spawned after February 2008 could match the availability of food (ice algae) at the under-ice surface or in the melt water layer just below (ice algae and phytoplankton). However, the numerous nauplii N3 in late February-early March may have fallen short of reaching the period of food availability, although they can withstand starvation for a period of at least one month (Jung-Madsen et al., 2013).

Several observations support the hypothesis of a top-down control of the $C$. hyperboreus population. First, daily egg production of 29000 eggs $\mathrm{m}^{-2}$ averaged over February-March and egg abundance throughout that period were the same. However, a much higher accumulation of eggs in the water column could be expected knowing that these eggs take approximately nine days to develop to stage N1 (Conover, 1988; Ji et al., 2012). The large deficit of eggs suggests the impact of predation. Second, the substantial numbers of eggs spawned throughout March did not translate into high numbers of young nauplii in late March and early April when reproduction lessened, indicating that eggs and/or nauplii likely suffered high mortality. Reduced egg 
viability after spawning is an alternative explanation to predation pressure for the poor recruitment in 2008. However, information on hatching success during this study is not available to support this. Interestingly, the steep increase in respiration per unit mass of the large mesozooplankton $>1000 \mu \mathrm{m}$ in mid-March at depth (Darnis and Fortier, 2012) corresponded to large release of $C$. hyperboreus eggs at depth and declining abundance of eggs and nauplii, but also to a time of low sympagic primary production in the inner surface of the ice. Thus, carbon supplied by these lipid-rich eggs and nauplii to the environment in winter should represent a crucial food resource for other zooplankton, such as omnivorous and carnivorous copepods like Metridia longa, Aetideopsis spp., Gaetanus spp., Gaidius spp., Paraeuchaeta glacialis, and chaetognaths, cnidarians and pelagic amphipods at a time of otherwise poor biological production. The abundant late copepodites of the congener species Calanus glacialis are also predators of $C$. hyperboreus eggs and nauplii (Frank-Gopolos et al., 2016).

Late developmental stages of $M$. longa consume eggs and nauplii of C. hyperboreus (Conover and Huntley, 1991; Darnis et al., 2012). Being distributed above the $C$. hyperboreus spawning females, stages CIV and adults of $M$. longa and C. glacialis were strategically positioned to intercept the Calanus eggs and nauplii floating toward the under-ice surface in February-March (Darnis and Fortier, 2014). Plourde et al. (2003) reported a negative relationship between the abundances of $C$. hyperboreus and $M$. longa over several years in the lower St. Lawrence Estuary. In 2008 in Amundsen Gulf, the population size of late stages CIV-Adult of $M$. longa and C. glacialis was about 3 times higher than in 2002 (Darnis et al., 2008), 2004 and at sites $>200 \mathrm{~m}$ depth outside Amundsen Gulf in 2007-2008, including the overwintering site in Franklin Bay (Fig. 9). By contrast, C. hyperboreus abundance did not differ significantly between 2004 and 2008, or among different areas of the southeastern Beaufort Sea. Therefore, a much-reduced C. hyperboreus/zooplankton predators abundance ratio in Amundsen Gulf in 2008 underlines the potential for stronger predation pressure on the eggs and young nauplii of $C$. hyperboreus. Results from the modeling approach of Dufour et al. (2016) suggest that females M. longa alone had a limited impact on $C$. hyperboreus egg biomass in 2008. The authors acknowledged that adding egg ingestion by M. longa CV and adult males, which were as abundant as females in winter 2008 (Darnis et al., in preparation), and predation on the more detectable motile Calanus early nauplii would certainly increase the impact of $M$. longa on $C$. hyperboreus in their simulations. In this study, the significant correlations found in 2008 between the abundances of stages CIV-Adult of $M$. longa and eggs and early nauplius stages of $C$. hyperboreus could mean that this omnivore copepod responded positively to the abundance of the $C$. hyperboreus youngest developmental stages. The $50-\mu \mathrm{m}$ plankton net used to sample the small zooplankton has certainly led to a severe underestimation of larger potential predators, including late copepodite stages of Metridia longa and other copepods, hampering any analysis of relationships between prey and potential zooplankton predators. By contrast, the $200-\mu \mathrm{m}$ mesh nets under-sampled the small Calanus eggs and nauplii. Thus, it would be difficult to use our abundance datasets to support a more thorough investigation of trophic interactions between the important Arctic species C. hyperboreus and other zooplankton, particularly since the taxonomic analysis of the two types of net samples was not necessarily done for the same stations in 2008. Nevertheless, results from a new study in Scandinavian fjords support our hypothesis that predation is a determinant factor of the Arctic Calanus populations loss in winter (Espinasse et al., 2018).

\section{Conclusion}

Tremblay et al. (2011) revealed that reduced sea-ice cover along with upwelling favorable atmospheric conditions boosted several-fold the production of ice algae, phytoplankton and of the key shelf species Calanus glacialis over the coastal Beaufort Sea in autumn 2007 and summer 2008, in comparison with respective periods in 2003 and 2004.
This was most likely the case also for Metridia longa in Amundsen Gulf. By contrast, our analysis of Calanus hyperboreus demographics in the deeper Amundsen Gulf fails to identify strong recruitment and population growth for this oceanic species in 2008 despite an $80 \%$ increase in total primary production compared to 2004 (Forest et al., 2011b). The short time lag of 1-3 months between a vigorous 2008 winter spawning and onset of the ice-algae bloom and precocious phytoplankton production refutes the scenario of a mismatch between the bulk of the first-feeding developmental stages and food availability to explain this rather poor recruitment. Population development, obviously, is not severely limited by environmental conditions in the southeastern Beaufort Sea since $C$. hyperboreus can condense its life cycle to a 2 to 3-year duration there, as in other arctic regions experiencing early onset of biological production. On the other hand, the copepods Metridia longa and Calanus glacialis, second and third players in terms of abundance as well as biomass in 2007-2008 in Amundsen Gulf (Darnis and Fortier, 2012), increased considerably their abundance in response to the relaxation of the ice regime and resulting favorable feeding conditions until late autumn 2007. We suspect that these abundant omnivores, along with other zooplankton predators, restrained population growth of $C$. hyperboreus by preying on its youngest stages during winter when other food sources are scarce (Conover and Huntley, 1991). With the ongoing lengthening of the icefree season due to climate change, thriving populations of opportunistic zooplankton could well intensify the top-down control of recruitment of the herbivore $C$. hyperboreus, possibly to the extent of counteracting the potential benefits of increased pelagic primary production over the margins of the arctic shelves. On the other hand, putative iteroparity in females and the multiple-year life cycle of $C$. hyperboreus may dampen the impacts of zooplankton predators on its population. Clearly, studies based on zooplankton multi-year time series and devoted to trophic interactions between $C$. hyperboreus and other zooplankton are required to better understand the fate of this key Arctic-endemic species under the effects of climate change.

\section{Acknowledgements}

We express our gratitude to the officers and crews of the CCGS Amundsen for their assistance at sea. We wish to thank numerous colleagues who contributed to the sampling and laboratory analyses during this 10-month fieldwork; we wish to thank: Caroline Bouchard, Alexandre Forest, Stéphane Thanassekos, Keith Lévesque, Catherine Lalande, Josée Michaud, Brigitte Robineau, Louis Létourneau, Luc Michaud, Marc Ringuette, Hélen Cloutier, Samuel Lauzon, Makoto Sampei, Anaïs Aubert, and Alexis Burt. We would also like to thank the coordinators of the Circumpolar Flaw Lead System Study (CFL), D. Leitch and M. Pucko, for the organization of the fieldwork. The CFL program and this study were funded by the Canadian International Polar Year (IPY) program office, the Natural Sciences and Engineering Research Council of Canada (NSERC), the Canada Research Chairs (CRC) Program, the Network of Centres of Excellence ArcticNet, and the Canada Foundation for Innovation (CFI). This is a contribution to Québec-Océan at Université Laval, ArcticNet, and the Canada Research Chair on the response of marine arctic ecosystems to climate warming. The project was also supported by the Norwegian Research Council ArcticABC (No .244319) and Marine Night (No. 226417) and by Statoil through the Statoil - ARCTOS Arctic Research Program (SAARP).

\section{Appendix A. Supplementary material}

Supplementary data to this article can be found online at https:// doi.org/10.1016/j.pocean.2018.11.004.

\section{References}

Arrigo, K.R., van Dijken, G.L., 2004. Annual cycles of sea ice and phytoplankton in Cape 
Bathurst polynya, southeastern Beaufort Sea, Canadian Arctic. Geophys. Res. Lett. 31. Arrigo, K.R., van Dijken, G.L., 2011. Secular trends in Arctic Ocean net primary production. J. Geophys. Res. 116, C09011.

Ashjian, C.J., Campbell, R.G., Welch, H.E., Butler, M., Van Keuren, D., 2003. Annual cycle in abundance, distribution, and size in relation to hydrography of important copepod species in the western Arctic Ocean. Deep Sea Res. Part I 50, 1235-1261.

Auel, H., Hagen, W., 2002. Mesozooplankton community structure, abundance and biomass in the central Arctic Ocean. Mar. Biol. 140, 1013-1021.

Barber, D.G., Hanesiak, J.M., 2004. Meteorological forcing of sea ice concentrations in the southern Beaufort Sea over the period 1979 to 2000. J. Geophys. Res. 109. https:// doi.org/10.1029/2003JC002027.

Benoit, D., Simard, Y., Fortier, L., 2008. Hydroacoustic detection of large winter aggregations of Arctic cod (Boreogadus saida) at depth in ice-covered Franklin Bay (Beaufort Sea). J. Geophys. Res. 113, 9.

Campbell, R.G., Sherr, E.B., Ashjian, C.J., Plourde, S., Sherr, B.F., Hill, V., Stockwell, D.A., 2009. Mesozooplankton prey preference and grazing impact in the western Arctic Ocean. Deep Sea Res. Part II.

Carmack, E.C., Macdonald, R.W., 2002. Oceanography of the Canadian Shelf of the Beaufort Sea: a Setting for Marine Life. Arctic 55, 29-45.

Conover, R.J., 1988. Comparative life histories in the genera Calanus and Neocalanus in high latitudes of the northern hemisphere. Hydrobiologia 167-168, 127-142.

Conover, R.J., Huntley, M., 1991. Copepods in ice-covered seas - Distribution, adaptations to seasonally limited food, metabolism, growth patterns and life cycle strategies in polar seas. J. Mar. Syst. 2, 1-41.

Conover, R.J., Siferd, T.D., 1993. Dark-season survival strategies of coastal zone zooplankton in the Canadian Arctic. Arctic 46, 303-311.

Darnis, G., Barber, D.G., Fortier, L., 2008. Sea ice and the onshore-offshore gradient in pre-winter zooplankton assemblages in southeastern Beaufort Sea. J. Mar. Syst. 74, 994-1011.

Darnis, G., Fortier, L., 2012. Zooplankton respiration and the export of carbon at depth in the Amundsen Gulf (Arctic Ocean). J. Geophys. Res. 117, C04013.

Darnis, G., Fortier, L., 2014. Temperature, food and the seasonal vertical migration of key arctic copepods in the thermally stratified Amundsen Gulf (Beaufort Sea, Arctic Ocean). J. Plankton Res. 36, 1092-1108.

Darnis, G., Robert, D., Pomerleau, C., Link, H., Archambault, P., Nelson, R.J., Geoffroy, M., Tremblay, J.É., Lovejoy, C., Ferguson, S.H., Hunt, B.P.V., Fortier, L., 2012. Current state and trends in Canadian Arctic marine ecosystems: II. Heterotrophic food web, pelagic-benthic coupling, and biodiversity. Clim. Change.

Dawson, J.K., 1978. Vertical distribution of Calanus hyperboreus in the Central Arctic Ocean. Limnol. Oceanogr. 23, 950-957.

Dufour, K., Maps, F., Plourde, S., Joly, P., Cyr, F., 2016. Impacts of intraguild predation on arctic copepod communities. Front. Mar. Sci. 3.

Espinasse, B., Tverberg, V., Kristensen, J.A., Skreslet, S., Eiane, K., 2018. Winter mortality in Calanus populations in two northern Norwegian fjords from 1984 to 2016. Polar Biol. 41, 1405-1415.

Falk-Petersen, S., Mayzaud, P., Kattner, G., Sargent, J., 2009. Lipids and life strategy of Arctic Calanus. Mar. Biol. Res. 5, 18-39.

Falk-Petersen, S., Pavlov, V., Timofeev, S., Sargent, J., 2007. Climate variability and possible effects on arctic food chains: The role of Calanus. In: Arctic Alpine Ecosystems and People in a Changing Environment, pp. 147-166.

Folch, J., Less, M., Stone Stanley, G.H., 1957. A simple method for the isolation and purification of total lipids from animal tissues. J. Biol. Chem. 226, 497-508.

Forest, A., Galindo, V., Darnis, G., Pineault, S., Lalande, C., Tremblay, J.-É., Fortier, L. 2011a. Carbon biomass, elemental ratios (C:N) and stable isotopic composition $(\delta 13 \mathrm{C}, \delta 15 \mathrm{~N}$ ) of dominant calanoid copepods during the winter-to-summer transition in the Amundsen Gulf (Arctic Ocean). J. Plankton Res. 33, 161-178.

Forest, A., Tremblay, J.-É., Gratton, Y., Martin, J., Gagnon, J., Darnis, G., Sampei, M., Fortier, L., Ardyna, M., Gosselin, M., Hattori, H., Nguyen, D., Maranger, R., Vaqué, D., Marrasé, C., Pedrós-Alió, C., Sallon, A., Michel, C., Kellogg, C., Deming, J., Shadwick, E., Thomas, H., Link, H., Archambault, P., Piepenburg, D., 2011b. Biogenic carbon flows through the planktonic food web of the Amundsen Gulf (Arctic Ocean): a synthesis of field measurements and inverse modeling analyses. Progr. Oceanogr. 91, 410-436.

Fortier, L., Cochran, J.K., 2008. Introduction to special section on annual cycles on the Arctic Ocean shelf. J. Geophys. Res. 113, 6.

Frank-Gopolos, T., Friis Møller, E., Gissel Nielsen, T., 2016. The role of egg cannibalism for the Calanus succession in the Disko Bay, Western Greenland. Limnol. Oceanogr n/ a-n/a.

Galley, R.J., Key, E., Barber, D.G., Hwang, B.J., Ehn, J.K., 2008. Spatial and temporal variability of sea ice in the southern Beaufort Sea and Amundsen Gulf: 1980-2004. J. Geophys. Res. 113, 18.

Grainger, E.H., 1965. Zooplankton from the Arctic Ocean and Adjacent Canadian Waters. J. Fish. Res. Board Can. 22, 543-564.

Henriksen, M.V., Jung-Madsen, S., Nielsen, T.G., Møller, E.F., Henriksen, K.V., Markager, S., Hansen, B.W., 2012. Effects of temperature and food availability on feeding and egg production of Calanus hyperboreus from Disko Bay, western Greenland. Mar. Ecol. Prog. Ser. 447, 109-126.

Hirche, H.-J., 1997. Life cycle of the copepod Calanus hyperboreus in the Greenland Sea. Mar. Biol. 128, 607-618.

Hirche, H.J., 2013. Long-term experiments on lifespan, reproductive activity and timing of reproduction in the Arctic copepod Calanus hyperboreus. Mar. Biol. 160,
2469-2481.

Hirche, H.J., Niehoff, B., 1996. Reproduction of the Arctic copepod Calanus hyperboreus in the Greenland Sea-field and laboratory observations. Polar Biol. 16, 209-219.

Hygum, B.H., Rey, C., Hansen, B.W., 2000. Growth and development rates of Calanus finmarchicus nauplii during a diatom spring bloom. Mar. Biol. 136, 1075-1085.

Ingram, R.G., Williams, W.J., Van Hardenberg, B., Dawe, J.T., Carmack, E.C., 2008. Seasonal circulation over the Canadian Beaufort Shelf. In: Fortier, L., Barber, D.G., Michaud, J. (Eds.), On Thin Ice: a synthesis of the Canadian Arctic Shelf Exchange Study (CASES). Aboriginal Issues Press, Winnipeg, pp. 13-36.

Ji, R., Ashjian, C.J., Campbell, R.G., Chen, C., Gao, G., Davis, C.S., Cowles, G.W., Beardsley, R.C., 2012. Life history and biogeography of Calanus copepods in the Arctic Ocean: an individual-based modeling study. Progr. Oceanogr. 96, 40-56.

Johnson, M.W., 1963. Zooplankton collections from the high polar basin with special reference to the Copepoda. Limnol. Oceanogr. 8, 89-102.

Jung-Madsen, S., Nielsen, T.G., Gronkjaer, P., Hansen, B.W., Moller, E.F., 2013. Early development of Calanus hyperboreus nauplii: response to a changing ocean. Limnol. Oceanogr. 58, 2109-2121.

Kosobokova, K., Hirche, H.J., 2009. Biomass of zooplankton in the eastern Arctic Ocean a base line study. Progr. Oceanogr. 82, 265-280.

Madsen, S.D., Nielsen, T.G., Hansen, B.W., 2001. Annual population development and production by Calanus finmarchicus, C. glacialis and C. hyperboreus in Disko Bay, western Greenland. Mar. Biol. 139, 75-93.

McMeans, B.C., Arts, M.T., Rush, S.A., Fisk, A.T., 2012. Seasonal patterns in fatty acids of Calanus hyperboreus (Copepoda, Calanoida) from Cumberland Sound, Baffin Island. Nunavut. Mar. Biol. 159, 1095-1105.

Niehoff, B., Madsen, S.D., Hansen, B., Nielsen, T.G., 2002. Reproductive cycles of three dominant Calanus species in Disko Bay, West Greenland. Mar. Biol. 140, 567-576.

NSIDC, 2010. National Snow and Ice Data Center. Arctic Sea Ice News and Analysis, updated frequently, http://nsidc.org/arcticseaicenews/index.html.

Ota, Y., Hattori, H., Makabe, R., Sampei, M., Tanimura, A., Sasaki, H., 2008. Seasonal changes in nauplii and adults of Calanus hyperboreus (Copepoda) captured in sediment traps, Amundsen Gulf, Canadian Arctic. Polar Sci. 2, 215-222.

Pasternak, A., Arashkevich, E., Tande, K., Falkenhaug, T., 2001. Seasonal changes in feeding, gonad development and lipid stores in Calanus finmarchicus and C. hyperboreus from Malangen, northern Norway. Mar. Biol. 138, 1141-1152.

Pickart, R.S., 2004. Shelfbreak circulation in the Alaskan Beaufort Sea: Mean structure and variability. J. Geophys. Res. 109. https://doi.org/10.1029/2003JC001912.

Plourde, S., Joly, P., Runge, J.A., Dodson, J., Zakardjian, B., 2003. Life cycle of Calanus hyperboreus in the lower St. Lawrence Estuary and its relationship to local environmental conditions. Mar. Ecol. Prog. Ser. 255, 219-233.

Richardson, A.J., Verheye, H.M., 1999. Growth rates of copepods in the southern Benguela upwelling system: The interplay between body size and food. Limnol. Oceanogr. 44, 382-392.

Riedel, A., Michel, C., Gosselin, M., LeBlanc, B., 2008. Winter-spring dynamics in sea-ice carbon cycling in the coastal Arctic Ocean. J. Mar. Syst. 74, 918-932.

Ringuette, M., Fortier, L., Fortier, M., Runge, J., Belanger, S., Larouche, P., Weslawski, J., Kwasniewski, S., 2002. Advanced recruitment and accelerated population development in Arctic calanoid copepods of the North Water. Deep Sea Res. Part II 49, 5081-5099.

Sargent, J.R., Falk-Petersen, S., 1988. The lipid biochemistry of calanoid copepods. Biol. Copepods Hydrobiol. 167-168, 101-114.

Scott, C.L., Kwasniewski, S., Falk-Petersen, S., Sargent, J.R., 2002. Species differences, origins and functions of fatty alcohols and fatty acids in the wax esters and phospholipids of Calanus hyperboreus, C. glacialis and C. finmarchicus from Arctic water. Mar. Ecol. Prog. Ser. 235, 127-134.

Stevens, C.J., Deibel, D., Parrish, C.C., 2004. Species-specific differences in lipid composition and omnivory indices in Arctic copepods collected in deep water during autumn (North Water Polynya). Mar. Biol. 144, 905-915.

Swalethorp, R., Kjellerup, S., Dunweber, M., Nielsen, T.G., Moller, E.F., Rysgaard, S., Hansen, B.W., 2011. Grazing, egg production, and biochemical evidence of differences in the life strategies of Calanus finmarchicus, C. glacialis and C. hyperboreus in Disko Bay, western Greenland. Mar. Ecol. Prog. Ser. 429, 125-144.

ter Braak, C.J.F., Šmilauer, P., 2002. CANOCO Reference manual and CanoDraw for windows User's guide: Software for Canonical Community Ordination (version 4.5). Microcomputer Power, Ithaca, New York.

Tremblay, J.É., Bélanger, S., Barber, D.G., Asplin, M., Martin, J., Darnis, G., Fortier, L., Gratton, Y., Link, H., Archambault, P., Sallon, A., Michel, C., Williams, W.J., Philippe, B., Gosselin, M., 2011. Climate forcing multiplies biological productivity in the coastal Arctic Ocean. Geophys. Res. Lett. 38, L18604.

Tremblay, J.E., Simpson, K., Martin, J., Miller, L., Gratton, Y., Barber, D., Price, N.M., 2008. Vertical stability and the annual dynamics of nutrients and chlorophyll fluor escence in the coastal, southeast Beaufort Sea. J. Geophys. Res. 113, 14.

Varpe, $\varnothing ., 2012$. Fitness and phenology: annual routines and zooplankton adaptations to seasonal cycles. J. Plankton Res. 34, 267-276.

Vinogradov, M.E., 1997. Some problems of vertical distribution of meso- and macroplankton in the ocean. In: Adv Mar Biol. Academic Press Ltd, London, pp. 1-92.

Wold, A., Darnis, G., Søreide, J., Leu, E., Philippe, B., Fortier, L., Poulin, M., Kattner, G., Graeve, M., Falk-Petersen, S., 2011. Life strategy and diet of Calanus glacialis during the winter-spring transition in Amundsen Gulf, south-eastern Beaufort Sea. Polar Biol. 34, 1929-1946. 